\title{
SIMESIM - THE MECHATRONIC SYSTEM FOR Neuro-Motor DisAbled Persons
}

\author{
FiliPOIU, I.D.; SEICIU, P.L.; LAURIAN, T. \& CARUTASU, N.
}

Abstract: The paper presents a mechatronic system for the rehabilitation of locomotor disabled persons. The system is based on a basic gait training at which there were added several sub-systems necessary for a complex and full recovery. The complete system will be realized by a team of interdisciplinary trained researchers and will be totally developed in the next two years. The system design and development were based on the latest achievements of human movement science, mechanism theory, medical science and IT. A complete and thorough simulation of the system was performed as a starting milestone of this project.

Key words: mechatronic system, locomotor rehabilitation, movement science
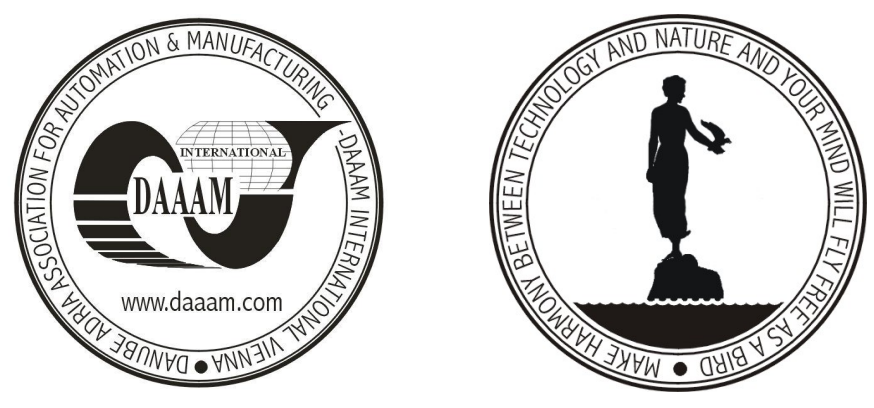

Authors' data: Ass. Prof. Filipoiu, I[oan] D[an]; PhD. Seiciu, P[etre] L[ucian]; $\mathrm{PhD}$. Laurian, T[iberiu]; Ass. Prof. Carutasu, N[icoleta], Polytechnic University Bucharest, 313 Splaiul Independentei, Bucharest, Romania, filipoiu@amcsit.ro, lucian.seiciu@as.info.ro, tlaurian@omtr.pub.ro,nicoleta@mix.mmi.pub.ro

This Publication has to be referred as: Filipoiu, I.D.; Seiciu, P.L.; Laurian, T. \& Carutasu, N. (2007). SIMESIM - The Mechatronic System For Neuro-Motor Disabled Persons, Chapter 34 in DAAAM International Scientific Book 2007, B. Katalinic (Ed.), Published by DAAAM International, ISBN 3-901509-60-7, ISSN 1726-9687, Vienna, Austria

DOI: $10.2507 /$ daaam.scibook.2007.34 